\title{
The Role of HWDI (Indonesian Association of Women with Disabilities) in Increasing the Self Confidence of Persons with Disabilities in Sukarame Bandar Lampung
}

\author{
Sri Ilham Nasution, Livia Cici Dahlia \\ Universitas Islam Negeri Raden Intan Lampung \\ sriilhamnasution@radenintan.ac.id
}

Submitted : 2021-06-30, Revised : 2021-07-05, Accepted : 2021-11-24

\begin{abstract}
This article examines the role of HWDI (Indonesian Women with Disabilities Association) in increasing the confidence of people with disabilities in Sukarame Bandar Lampung, where women with disabilities always feel inferior, have low self-esteem, do not have confidence when socializing and are in the midst of society. This paper aims to increase the self-confidence of people with disabilities using group guidance techniques. This research was conducted at HWDI (Indonesian Women with Disabilities Association) Sukarame Bandar Lampung. This research data collection using interviews, observation and documentation with the Snowball sampling technique. Data analysis in this study used descriptive qualitative data validity by means of triangulation and so on. The results of this paper indicate that the process of implementing group guidance for women with disabilities in HWDI is carried out in four stages: the first stage is the formation, the second is the transition, the third is the activity and the fourth is the termination using the Humanistic approach. These four stages can increase the confidence of women with disabilities at HWDI (Indonesian Disabled Women Association) Sukarame Bandar Lampung.
\end{abstract}

Keywords: Confidence; Group counseling; Women with Disabilities

\section{Introduction}

In early 2016, Indonesia passed the Law on Persons with Disabilities. One of the fundamental changes is the change in the term from 'persons with disabilities' to 'persons with disabilities' (Millati, 2016). The use of this new term is felt to be more appropriate because it changes the perspective where previously disabled people referred to medical damage, while disability is a view of barriers to social participation due to physical, mental or environmental factors that do not accommodate (Gal et al., 2010). Disability is a natural part of human diversity. So that it is natural to get equal recognition and respect, not to be pitied and discriminated against. In addition to the two terms above, there is a third term, namely disability. Based on law no. 8 of 2016, persons with disabilities are people who experience physical, intellectual, mental and sensory limitations for a long period of time who in interacting with the environment can experience obstacles and difficulties to participate fully and effectively with other citizens based on equal rights (Utami et al., 2019). A physical or mental condition related to the structure of the body; activity limitations are difficulties faced by individuals in carrying out tasks or actions; while participation restrictions are problems experienced by individuals involved in life situations. Therefore, disability is not just a matter of self-confidence, but a complex phenomenon that reflects the interaction between a person and the society in which he or she lives. Research (Rahakbauw \& Salakory, 2018) reveals that the forms of protection received by women with disabilities are: social assumptions, social assistance and social empowerment, where the obstacles faced in accessing services are unequal information discrimination and limitations. physical and discriminatory treatment from the community as well as public facilities that are not accessible to persons with disabilities. In contrast to the opinion (Apsari, 2018) according to him that the role of HWDI in assisting victims of sexual violence against women with disabilities is social assistance, health assistance, and what becomes an obstacle in mentoring is from the victim's family and law enforcement officers law. 
The emphasis on the meaning of disability in this concept is that there is a long-lasting functional impairment and causes limited participation in society. Director of Poverty Reduction and Social Welfare at the Ministry of National Development Planning/Bappenas, Vivi Yulaswati, said that the BPS Intercensus Population Survey or Supas in 2015 showed the number of people with disabilities in Indonesia was 21.5 million people. This number continues to grow every year. The data is far more illustrative of the number of people with disabilities in Indonesia than the previous three-year survey, namely in 2012.

Persons with disabilities always have difficulty when doing activities and always feel inferior, not confident to adjust to the environment around them, not infrequently often get different treatment from others. Like research (Armas et al., 2017) people with disabilities in entrepreneurship have a positive self-concept that fosters a sense of self-confidence in people with disabilities, even though initially they have a negative self-concept when experiencing and feeling their limitations which are influenced by perceptions from within (in self) and perceptions from outside of persons with disabilities (out self). There are several factors that make the self-concept of persons with disabilities change from initially having a negative selfconcept and turning into a positive self-concept before starting and running entrepreneurship, namely: (1) Motivation from within, (2) Motivation from outside and providing explanations with a good way about the initial condition of persons with disabilities from their families, (3) attend public schools and special schools, (4) participate in rehabilitation, (5) be active in associations or social communities, both communities with disabilities and mixed with nondisabled. In addition, persons with disabilities in entrepreneurship have good communication competence (aware and competent in communication) which provides improvements to their business activities.

Research (Agustini \& Susilarti, 2014) states that the level of self-confidence of students in three dormitories in Yogyakarta after using the Fixed Orthodoxy tool is dominated by the category of high level of confidence, namely the category of high self-confidence as many as twenty respondents (Ninety-nine percent) while two respondents had low self-confidence (Nine point one percent). Then research based on the results of post-test observations or observations on subjects that was hypothesized on initiative stuttering behavior through conversation with people and aloof behavior that resulted in significant changes (Louis et al., 2020). Increased confidence in people with visual impairments after using Cognitive Behavior. According to Sari dan Yendi (2018), there is a need for Guidance and Counseling teachers or Counselors to develop the practice of guidance and counseling services to improve the quality or potential of students with physical disabilities in increasing their self-confidence and the factors that influence the self-confidence of students with physical disabilities so that the emergence of insecurity that makes him withdraw from the environment.

Based on these phenomena, this research on Increasing the Confidence of Women with Disabilities in the Sukarame Bandar Lampung (HWDI (Indonesian Women with Disabilities Association) Institute examines how the implementation of group guidance with group discussion techniques in increasing the self-confidence of women with disabilities and is there any result of increasing the self-confidence of women with disabilities in The Indonesian Women with Disabilities Association Sukarame Bandar Lampung.

\section{Method}

The writing of this article uses a qualitative approach, in collecting research data using observation, interviews, documentation with the Snowball Sampling technique, namely the technique of determining the number of informants who were initially small, then enlarged, namely at the beginning of the study the number of informants used was small but from time to time. can be increased according to the needs of the data in completing it, with the criteria 
of supervisor informants who already have expertise or work at least 1 year at HDWI then respondents with disabilities are born. namely the technique of determining the number of informants who were initially small, then enlarged. Then in the data analysis technique using the steps proposed Miles dan Huberman (1992) the implementation of the data analysis technique has 3 stages, the first is data reduction, the second is data display (data presentation), the third step is drawing conclusions and verification.

\section{Results and Discussion}

As research reveals that: Group guidance with out bound techniques is effective for improving students' self-adjustment (Subagyo, 2013). Similarly, the implementation of group guidance is guided by a supervisor which is carried out in several stages:

This first stage is the introduction stage, involving a mentor in the group, where the supervisor has the task of guiding and directing the course of the group discussion. As a result of the observation that the Sukarame Indonesian Women with Disabilities Association, the group guidance steps are as follows:

a. The group leader explains to the members to introduce themselves to each other so that they can get to know each other, so that in the discussion group can build a familiarity and closeness with each other.

b. The group leader explains what are the principles that apply in group guidance, namely the principles of openness, confidentiality, independence, volunteerism, activities, expertise, handayani and dynamism. Thus, what has been conveyed by members in the group discussion may not be known by other group members.

The second stage is the transition stage. This stage is the formation stage. This formation stage is the stage of introduction and group formation. Mrs Siti Khodijah as the supervisor revealed that: At this stage, the supervisor is directly involved in leading and explaining the purpose of group guidance. This introductory stage is still shy, all group members understand each other, trust and are open to each other so that the activities can be carried out properly. Mrs Siti Khodijah said, "At first I directed them, we sat in a circle and faced each other, then each member introduced himself to create a comfortable atmosphere that was not awkward because all members have disabilities". At this stage the group leader explains to his members for the next stage and asks each member, is it clear for the next stage, for the continuation of the next stage, whether all members understand for the next activity. Mrs. Maryatun HWDI Secretariat said "Are all of you guys ready for the next discussion, sometimes I also ask some points about the initial activity. After the leader discussed and explained it, it only started to look serious when the leader explained it."

The third stage of activity. At this stage, the group supervisor provides the opportunity for its members to discuss in accordance with the topics that have been determined by the supervisor, namely about the first stage how to increase self-confidence in the second stage what are the factors that cause low self-confidence, in the third stage it is continued by increasing self-confidence. confident and at the next stage, namely at the final stage how to maintain that confidence. In carrying out this discussion, HWDI members experienced difficulties with the topics that had been determined. This is a challenge for the supervisor to be able to guide his group members so that they can feel comfortable in the discussion, not feel awkward and embarrassed. Mrs Siti Khodijah said: at this stage, the supervisor is also looking for factors that cause low self-esteem. At this stage, the supervisor must be able to realize his role as a mentor, so that members do not feel inferior, have the confidence to be able to get a job. Ibu Siti Khodijah said, "This activity is the peak activity, where members usually feel anxious, or afraid of themselves because they really feel they are not being liked. That's why 
it's difficult to convey it because it's new." Mrs Siti Khadijah shared her experience "she felt anxious when she first joined the group guidance because she became disabled because of an accident and her condition changed drastically. When talking about self-confidence, he feels down because before, he was a swimmer, since an accident that made his left leg unable to straighten so it is difficult for him to swim again, because he is not used to it."

The fourth stage is the termination stage. At this stage, the group supervisor and members present the results of their discussions and also convey that this group discussion activity will end. At that time the group leader asked his group members to convey the message and his impression of why they did not feel confident in adapting to the community. Followed by the leadership's explanation that this is the last discussion and briefly review the topics that have been discussed previously, that self-confidence is necessary to socialize with the community and will disappear by itself if we feel inferior and have low self-esteem. And at this final stage, HWDI members have shown an attitude of confidence and dared to invite members to convey their impressions and convey to their members that this will not only end here but will continue anytime, anywhere. The group supervisor reminded that this does not just stop here but is continuous and can be applied so as not to feel embarrassed or awkward in the midst of society. At this last stage, group members are brave and have confidence when each individual is asked to convey his message and impression. In the words of Siti Khodijah, "HWDI members have started to look confident, they have been noticed from the start and before the group guidance was conducted.....and thank God there have been changes for the better.

Through the four stages of the group's guidance, women with disabilities at HWDI (Indonesian Women with Disabilities Association) Sukarame Bandar Lampung, have been able to increase their self-confidence. Through skills training in the local area, such as learning to sew, learning to operate a computer, learning to cook and so on, it can be used as a means to increase self-confidence, because during this kind of training the members are not always with disabilities. An interview with Indah Hartati, the HWDI secretariat, revealed, "if the problem is the schedule of implementation once a week, it depends on the situation because sometimes it is scheduled but cancelled, with training activities, if there are overlapping schedules, the implementation will use a short time or come rather early than the schedule. the specified schedule so that the activities can continue to be carried out, the important thing is that the objectives are achieved."

Based research Jarmitia (2014) revealed that there is a positive and significant relationship between social support and self-confidence in people with physical disabilities in special schools in Banda Aceh. The higher the social support, the higher the trust in persons with disabilities in special schools in the city of Banda Aceh. Likewise with disabilities in the HWPI (Indonesian Women with Disabilities Association) institution Sukarame Bandar Lampung. With the belief that women with disabilities will be able to compete among women in general, there is no feeling of inferiority, inferiority and shyness. Based on this paper, women with disabilities in the HWPI (Indonesian Women with Disabilities Association) institution, Sukarame Bandar Lampung, experienced changes from the beginning before receiving group guidance and after receiving group guidance:

a. Confidence before receiving group guidance. Women with disabilities are always underestimated by normal people, this is what makes women with disabilities feel inferior, inferior when they are in the midst of society, as stated by Rusmiya HWDI Secretariat.

b. Confidence after getting group guidance. After the implementation of group guidance, women with disabilities began to show the results of reducing feelings of inferiority. Feelings of inferiority, inferiority, lack of self-confidence have begun to decrease. As Siti Khodijah said "that not all normal people consider women with low disability to 
be, everyone has the same rights, no different, even though there are physical shortcomings". The HWDI Secretariat Rusmiyah stated that "the feeling of inferiority and lowliness is only in my mind". Confidence After Getting Group Guidance in accordance with Humanistic theory (Habsy, 2014).

c. Reduced feelings of inferiority. After following the group guidance, the disabled members who previously felt inferior, afraid, embarrassed, and lacking in selfconfidence are now starting to be brave, because after receiving guidance, motivation and enthusiasm, as conveyed by Mrs Siti Khodijah as the supervisor, show yourself, you can and you can. have the right to get a job like normal people, that not all normal people think women with disabilities are weak, have no ability. The group supervisor felt a little relieved, seeing that the disabled members had shown changes even though the changes were not yet fully visible because it took time to make changes.

d. Have the courage to make changes. Through the observations that the author sees that women with disabilities have dared to show their attitude, they don't feel inferior and have low self-esteem anymore. Through the guidance of the group members with disabilities have been able to understand that being afraid of being inferior is inhibiting all their activities to grow and develop. In the end they realized that happiness is not only from a perfect physical but a calm heart feeling, being able to share and help each other among others. As Mrs Indah said that "the physical deficiency we have is not an obstacle for us to work, this is a trial as well as a gift from Allah SWT." Thus, having the confidence to socialize in society without feeling inferior, fearful and shy can make him calm and happy. Group guidance is a place or forum for discussion, exchange of ideas, mutual openness and mutual respect for one another. By attending training, members with disabilities can develop their talents and skills.

\section{Conclusions and Suggestions}

Based on the results of these studies, it can be concluded that the technique of increasing the confidence of women with disabilities at the Sukarame Bandar Lampung HWDI (Indonesian Women with Disabilities Association) in the implementation of group guidance was carried out in four stages, namely: the initial stage, the transition stage, the activity stage and the final stage. The implementation of this group guidance aims to increase the selfconfidence of women with disabilities. In addition to the implementation of group guidance, activities are in the form of training as an effort to increase self-confidence and train the talent skills possessed by women with disabilities. In carrying out its activities, it uses a Humanistic approach, namely humanizing humans. Where in this Humanistic theory views humans as active creatures that are able to be invited to discuss, not only driven by regulations. But more to feelings, and attitudes towards fellow human beings. The results of this research are expected that HWDI can maintain the strategies that have been implemented in local institutions and the government is expected to pay attention to and provide equal rights for women with disabilities.

\section{References}

Agustini, D. N., \& Susilarti, S. (2014). Efek Pemakaian Alat Orthodonsi Cekat Terhadap Tingkat Percaya Diri Mahasiswa Pada Tiga Asrama Daerah Di Yogyakarta. Journal of Oral Health Care, 1(1), 56-64.

Apsari, N. C. (2018). Peran Lembaga Himpunan Wanita Disabilitas Indonesia (HWDI) bagi Perempuan Tuna Rungu Korban Pelecehan Seksual. Prosiding Penelitian Dan Pengabdian Kepada Masyarakat, 5(1), 73-82.

Armas, A. M., Unde, A. A., \& Fatimah, J. M. (2017). Konsep Diri dan Kompetensi Komunikasi Penyandang Disabilitas dalam Menumbuhkan Kepercayaan Diri dan Aktualisasi Diri di 
Dunia Kewirausahaan Kota Makassar. KAREBA: Jurnal Ilmu Komunikasi, 6(2), 277-284.

Gal, E., Schreur, N., \& Engel-Yeger, B. (2010). Inclusion of Children with Disabilities: Teachers' Attitudes and Requirements for Environmental Accommodations. International Journal of Special Education, 25(2), 89-99.

Habsy, B. A. (2014). Teori dan pendekatan konseling modern dan post modern. Jombang: Undar Press.

Jarmitia, S. (2014). Hubungan antara dukungan sosial dengan kepercayaan diri pada penyandang disabilitas fisik di SLB Kota Banda Aceh. ETD Unsyiah.

Louis, K. O. S., Węsierska, K., Przepiórka, A., Błachnio, A., Beucher, C., Abdalla, F., Flynn, T., Reichel, I., Beste-Guldborg, A., \& Junuzović-Žunić, L. (2020). Success in changing stuttering attitudes: A retrospective analysis of 29 intervention studies. Journal of Communication Disorders, 84, 105972.

Miles, M. B., \& Huberman, A. M. (1992). Analisis data kualitatif. Jakarta: UI press.

Millati, S. (2016). Social-Relational Model dalam Undang-undang Penyandang Disabilitas. INKLUSI Journal of Disability Studies, 3(2), 285-304.

Rahakbauw, N., \& Salakory, D. M. (2018). Perlindungan Sosial Bagi Perempuan Disabilitas (Studi di Himpunan Wanita Disabilitas Indonesia (HWDI) Maluku). ARISTO, 6(1), 145163.

Sari, I. P., \& Yendi, F. M. (2018). Peran Konselor dalam Meningkatkan Kepercayaan Diri Siswa Disabilitas Fisik. SCHOULID: Indonesian Journal of School Counseling, 3(3), 8088.

Subagyo, I. (2013). Bimbingan kelompok dengan teknik outboun. Jurnal Bimbingan Konseling, 2(2).

Utami, N. S., Prasetyoningsih, N., Hidayat, A., Huda, N. M., Suteki, S., Saraswati, R., \& Budiono, A. (2019). Equality of the political rights of people with mental disorders (PWMD) in general elections. Indian Journal of Forensic Medicine \& Toxicology, 13(4), 1571-1575. 